\title{
Crick's resignation heralds new era for Salk
}

San Diego. The surprise resignation of Francis Crick from his brief stay as president of the Salk Institute, announced last week, marks a generational changing of the guard at the research facility in La Jolla, California.

Crick, who is 79 , has worked at the institute since 1976 and was president for less than a year. His resignation, coming only weeks after the death of the institute's founder Jonas Salk, ushers in a new era for the institute, which, in recent times, has had difficulties appointing and keeping presidents.

Crick, who shared the Nobel prize with James Watson for their discovery of the molecular structure of DNA, leaves the post this week because of ill-health. $\mathrm{He}$ underwent coronary angioplasty in June. He declines to comment on his resignation, but a press release from the Salk says that he plans to continue his research in theoretical neurobiology at the institute.

Inder Verma, a gene therapy researcher who is vice-chairman of the institute, says that the institute is now casting its net wide for a leading researcher to take over the position. "The currency of the institute is science, so we believe a scientist would be most effective - someone who has vision and a lot of desire to do fund raising", he says. He hopes to see the post filled by November. Given the institute's halting efforts at finding new presidents, this timetable may be a little optimistic.

After Frederic de Hoffmann's 15-year

\section{More delays at Mount Graham}

Boston. An appeals court last month rejected a plea from the University of Arizona and the US Forestry Service to lift an injunction on construction of the Large Binocular Telescope (LBT) at Mount Graham in Arizona. The judgement could delay the beleagured project for years.

Construction at the site has been blocked since May 1994, following a lawsuit by a coalition of environmental groups who claim that it threatens an endangered species of red squirrel indigenous to the mountain (see Nature 370, 407; 1994).

The court ordered a full environmental impact study to be undertaken, something that astronomers fear could result in a series of appeals and counterappeals.

To complicate matters even more, the tribal council of the local San Carlos Apache Tribe, which holds the mountain sacred, but which was officially neutral on the project until very recently, expressed in June its total opposition to the telescope. The Forest Service is now reviewing the tribe's request that the mountain be considered a "Traditional Cultural Property and Sacred Site" subject to protection under the National Historic Preservation Act.

Scientists hardened by the decadelong dispute are taking the latest developments in their stride. Two telescopes are already operating on Mount Graham, and 1.5 acres of spruce fir forest have already been cleared for the LBT. "All that remains to be cleared is one quarter of an acre, on a mountain that has nearly 200,000 acres of National Forest land", says Bruce Walsh, a biologist at the University of Arizona.

Walsh and his colleagues dismiss the red squirrel argument, saying that five years of daily monitoring has failed to turn up any evidence of squirrel activity at the site in dispute. "It really does seem to be an anti-science battle", says Peter Strittmatter, director of the Steward Observatory.

The LTB consortium, which includes the University of Arizona, the Research Corporation of Tucson and the Arcetri Observatory in Florence, Italy, meets this week to consider its options. One possibility would be to return to the original site on the mountain which had already been approved by the federal government in 1988. The consortium voluntarily abandoned this site because biologists at the University of Arizona suggested that the second site would be less disruptive to the squirrels.

The second possibility is to proceed with the environmental review: "but by the end of it astronomers could be further away from their goal than they are now", says Richard Kvale, District Ranger for the Forest Service.

Work on the telescope is continuing offsite, despite the facility's uncertain future. Final structural designs of the LBT, which are being prepared by two Italian companies, should be completed this autumn. Preparations are also underway to cast the LBT's 8.4-metre glass mirrors at the University of Arizona.

"This telescope is going to be built", insists Strittmatter. "It is too important for it not to be built." Among other things, the LTB will be capable of seeing faint objects in the sky such as early-forming galaxies and sheets of dust around the Sun and other stars.

Greatly needed assistance may come from US Representative Jim Kolbe (Republican, Arizona) who announced last week that he will propose new legislation in an attempt to end construction delays.

Steve Nadis tenure as president ended in 1988, when ill-health forced his resignation, there was a four-year search for a replacement, with the 81-year-old Nobel prizewinner Renato Dulbecco filling in.

During the hunt, two candidates fell by the wayside, one even rejecting an offer that included a new presidential home to be built adjacent to the institute overlooking the

IMAGE
UNAVAILABLE
FOR COPYRIGHT
REASONS

Crick: no comment.

ocean. Brian Henderson, a physician hired largely for his fund-raising capabilities, was appointed but stayed only 20 months.

But there is one major factor that may make the presidential search more productive this time round - the absence of Salk himself. Although he was popular with the general public for his development of the polio vaccine, Salk's relationship with the scientific community was more complex.

After Hoffman left in 1988, Salk assumed a more prominent role at the institute than he had for years. He also helped to found the Immune Response Corporation, a public company that is trying to develop an AIDS vaccine. And Salk became an outspoken proponent of scientific approaches to an AIDS vaccine that were sharply criticized by some leading immunologists.

In his final years, Salk was scorned by some scientists who claimed that he acted as a stock promoter who manipulated research announcements at scientific conferences with an eye more towards the stock market than peer-reviewed publications.

However, at his institute, Salk's presence was "ethereal", says Verma. "It was like going to your parents' house. You sleep well, knowing that they are there. Jonas was like that; his presence was reassuring." But with the patriarch of the house of Salk gone, it might be easier to find a new head of the household; one who won't have to share the seat at the head of the table.

Rex Dalton 